\title{
INTEGRAR. CONCILIAR. PARTIR: AS CORTES DE LISBOA ENTRE PORTUGUESES DE AMBOS OS HEMISFÉRIOS (1821-1822)
}

ALEXANDRE BELLINI TASCA

UNIVERSIDADE FEDERAL DE MINAS GERAIS

BELO HORIZONTE - MINAS GERAIS - BRASIL

No dia 24 de agosto de 1820 eclodiu em Portugal a "Revolução do Porto", movimento que deu origem às Cortes de Lisboa. O objetivo deste artigo é analisar os principais traços da dinâmica que se fez presente nos embates discursivos dessa assembleia, entendida aqui como instituição fundante do constitucionalismo moderno lusobrasileiro. A discussão partirá de uma análise das linguagens que formaram o ideário político vintista, com enfoque nos debates acerca da

RESUMO origem e do exercício do poder soberano, que se relacionariam com as pretensões de transformar Portugal no que Fernando Catroga denomina um Estado-nação Império. Conclui-se que as disputas e desentendimentos fomentados pelas Cortes de Lisboa nesse sentido gestacionaram projetos para a formação do Brasil enquanto nação independente.

Palavras-chave: Soberania; Cortes de Lisboa; Constitucionalismo.

On August 24, 1820, the "Porto Revolution" broke out in Portugal, a movement that gave rise to the Lisbon Courts. The purpose of this article is to analyze the main aspects of the dynamics that were present in the discursive pleading of this assembly, understood here as the founding institution of modern Portuguese-Brazilian constitutionalism. The discussion will start from an analysis of the languages that formed the ABSTRACT "vintista" political set of ideas, focusing on the debates about the origin and the exercise of sovereign power that would relate to the intentions of transforming Portugal into what Fernando Catroga calls an Estadonação Império. It is concluded that the disputes and disagreements fomented by the Lisbon Courts in this sense have generated projects for the formation of Brazil as an independent nation.

Keywords: Sovereignty; Lisbon Courts; Constitutionalism.

* Doutorando em História e Culturas Políticas pela Universidade Federal de Minas Gerais. Professor da Rede Municipal de Educação de Belo Horizonte (Escola Municipal Maria Silveira). E-mail: abtasca@gmail.com. 


\section{INTRODUCÃO}

Entre 26 de janeiro de 1821 e 04 de novembro de 1822 funcionaram em Lisboa as Cortes Gerais, Extraordinárias e Constituintes da Nação Portuguesa, talvez o principal órgão instituído pelo movimento vintista que tomaria o controle do governo de Portugal nos últimos meses de 1820, a partir da chamada Revolução do Porto. Isso porque, pela primeira vez, as Cortes portuguesas assumiam funções que iam muito além de seu tradicional caráter consultivo, arrogando para si funções deliberativas e, principalmente, constituintes. Na prática isso significou que homens eleitos nas diversas partes do Reino Unido de Portugal, Brasil e Algarves assumiam o exercício da soberania nacional portuguesa, antes concentrada nas mãos do monarca, e se tornavam responsáveis pelo processo de, como se dizia à época, "regenerar a Nação Portuguesa".

O objetivo deste artigo é analisar os principais traços da dinâmica que se fez presente nos embates discursivos das Cortes de Lisboa, entendida aqui como instituição fundante do constitucionalismo moderno luso-brasileiro ${ }^{1}$. Nesse sentido, o primeiro passo dado será analisar o processo de transformação da soberania e em como isto se relaciona com a constituição do Estado-nação império ${ }^{2}$ português. Em seguida, serão identificadas linguagens do ideário político ${ }^{3}$ presentes nas Cortes que irão nos localizar discursivamente em nossa análise documental. Por fim, será considerado o contexto interno dos discursos que nos permitirá avaliar os mecanismos de convencimento, ataque e defesa das ideias e projetos em pauta e o externo, que indica as bases sobre as quais se sustentariam as falas dos deputados expondo aspectos conflitivos presentes na elaboração da Constituição para a nação portuguesa, mas que estão além dos registros propriamente ditos das falas realizadas pelos deputados.

O Diário das Cortes foi o periódico responsável por publicar oficialmente a transcrição dos debates travados diariamente nas sessões das Cortes, processo que marca

\footnotetext{
${ }^{1}$ Cf.: GOMES, David Lopes. A Constituição de 1824 e o problema da modernidade: o conceito moderno de Constituição, a história constitucional brasileira e a teoria da Constituição no Brasil. Belo Horizonte: Editora D’Plácido, 2019.

${ }^{2}$ A designação de "Estado-nação império" aqui utilizada é tomada de empréstimo do historiador português Fernando Catroga que, em seu livro A geografia dos afectos pátrios (2014), busca compreender o processo de centralização do Estado português, desejoso de se manter como império desde a ascensão da monarquia constitucional, quando Portugal se tornaria um Estado-nação, até fins do Estado Novo.

${ }^{3}$ Ao dizer de linguagens do ideário políticos buscamos nos aproximar da proposta de J.G. A. Pocock (2013), que parte dos discursos e dos atos de fala para compreender dinâmicas transformações políticas de um determinado contexto. Assim será adaptada a abordagem de parte da historiografia que busca estabelecer a posteriori a atuação de "grupos" políticos no interior das Cortes. Embora auxilie no entendimento dos projetos que disputavam espaços no debate, a associação de indivíduos a certos "grupos" ou "banca das" acaba por, em alguma medida, perder de vistas a fluidez e os lances discursivos efetuados pelos deputados no ato de disputa específica, fosse ela de cunho estritamente público, fosse por valores morais particulares.
} 
a transformação política intentada pelo liberalismo. O povo-cidadão que se formava assumia seu papel nos assuntos públicos. O rei, de executor da potestas, que "originariamente" seria divina, torna-se apenas chefe do poder executivo, cidadão da Nação portuguesa, como os demais, sendo destituído de sua sacralidade. Os esforços vintistas direcionar-se-iam para o reconhecimento da constitucionalização da soberania, agora nacional, sufragada e escrita, processo que formaria o que Catroga denomina pátria iuris. O pertencimento à pátria portuguesa significaria "viver sob as garantias oferecidas pela lei sufragada, o que equivalia a não se ser 'servil', mas livre"4.

Entre janeiro de 1821 e setembro de 1822, em Lisboa, deputados eleitos por diversas províncias do Reino Unido de Portugal, Brasil e Algarves se reuniram em um esforço comum de constitucionalizar um Estado-nação imperial. Ou seja, buscaram juntar, sob as mesmas leis, um território descontínuo, dividido por oceanos, habitado por uma população plural, composta por europeus, nativos da América, Ásia, África, livres, escravizados e ex-escravizados, pelos seus descendentes e por imigrantes diversos que, ao longo dos séculos, interagiram, gerando uma enorme multiplicidade também cultural.

\section{A SOBERANIA EM DEBATE}

As Cortes de Lisboa foram formadas por homens ligados às camadas média e alta da elite, entre eles comerciantes, profissionais liberais, aristocratas, nobres, lavradores, senhores de engenho, membros da Igreja etc. Eram uma minoria se pensada diante da multidão de negros, pardos, escravizados, mulheres e pobres que compunham a população daquela pretendida nação. Esse é apenas um dos ruídos desse processo. A comunicação entre Portugal e Brasil através do vasto oceano Atlântico é também central para o entendimento desse contexto. As falhas e ausências no diálogo abrem margem para uma análise que considere o Reino do Brasil e as Cortes não como um conjunto uno, mas como ambientes distintos, embora articulados.

Assim, enquanto em janeiro de 1821 os vintistas já preparavam em Lisboa os últimos detalhes para o início das Cortes constituintes, que teve sua primeira sessão no dia 26 daquele mês, no Brasil, a chegada das notícias dos eventos decorrentes do 24 de

${ }^{4}$ CATROGA, Fernando. A geografia dos afectos pátrios: as reformas político-administrativas (séc. XIX-XX). Coimbra: Edições Almedina, 2014, p. 277. 
agosto provocava suas primeiras consequências concretas, como a adesão da província do Grão-Pará aos liberais do Porto, no dia $1^{\circ}$ de janeiro de 1821 . Outro exemplo dessa disparidade aparece quando, em 17 de julho de 1822, as Cortes declaravam a nulidade do decreto de D. Pedro, de 16 de fevereiro, que convocava um Conselho de Procuradores para auxiliá-lo na regência do Reino do Brasil. Enquanto isso, na América tal Conselho já havia se instalado, e mais, desde junho daquele ano, foram decretadas pelo príncipe instruções para eleição de uma Assembleia Constituinte no Brasil.

Esse último decreto seria visto pelas Cortes como o principal passo em direção ao separatismo. Havia uma tensão em termos da forma como cada uma das partes da nação estariam representadas no processo constituinte. Em Lisboa reuniram-se inicialmente apenas deputados eleitos pelas províncias peninsulares, que colocavam as Cortes como entidade máxima de poder, responsável pelo exercício da soberania, uma vez que representante da Nação Portuguesa. Tais funções foram definidas na "Secção II - Da Nação Portuguesa, sua religião, governo e dinastia" das Bases da Constituição ${ }^{5}$. Os $\operatorname{artigos} 20^{\circ}$ e $21^{\circ}$ determinavam, respectivamente, que a soberania residia essencialmente na Nação e que somente à Nação cabia fazer a Constituição por meio de seus representantes legitimamente eleitos. Já os artigos $24^{\circ}$ e $25^{\circ}$ estabeleceram que a lei é a vontade dos cidadãos, declarada por seus representantes reunidos em Cortes e que a sua iniciativa dizia respeito a esses mesmos representantes ${ }^{6}$. Desvinculavam, portanto, o poder soberano da figura real, que seria o chefe do poder executivo, mas não superior aos poderes legislativo e judiciário. Mais do que isso, institucionalizavam o poder legislativo, através das Cortes, como o principal centro do poder político em Portugal, uma vez que composto pelos representantes legitimamente eleitos pela Nação Portuguesa, verdadeira detentora da soberania.

Os debates que resultaram na definição de que a soberania, entendida como poder político supremo e autônomo, seria pertencente à Nação $^{7}$ e exercido pelos seus representantes tiveram que, a partir daí, se adequar ao conjunto da população nacional,

\footnotetext{
5 As Bases da Constituição da Monarquia Portuguesa foram apresentadas para as Cortes de Lisboa em Sessão de 8 de fevereiro de 1821 , se tornando o centro dos debates no mês que se seguiu, sendo assinada em 9 de março, ainda que com algumas pendências. No período nenhum deputado eleito por províncias do Brasil havia assumido assento na assembleia constituinte lisboeta e, portanto, não participaram do debate, nem da redação do documento.

${ }^{6}$ PORTUGAL. Bases da Constituição da Monarquia Portuguesa. Lisboa: Tipografia de J. F. M. de Campos, 1821.

${ }^{7}$ Ressalta-se que esta é uma definição legal e, embora pretenda legitimar-se como hegemônica, outros entendimentos da relação entre soberania e a Nação disputariam o espaço político e seriam mobilizados, mesmo após a concretização da Constituição.
} 
que não possuiria súditos, mas apenas cidadãos com funções distintas em um mesmo grupo. Um dos principais pontos levantados por esse deslocamento dizia respeito ao poder de veto que o rei teria perante as leis compostas pelo legislativo. Duas alternativas foram confrontadas: o veto absoluto e o veto suspensivo, com ainda uma terceira alternativa, minoritária, contra qualquer possibilidade de veto por parte do rei. Essa discussão ocorreu juntamente com a decisão acerca da adoção de um sistema bicameral ou unicameral, temas discutidos após se definir a soberania como pertencente em essência à Nação. Ao se posicionarem, alguns deputados expuseram posições que evidenciavam as mudanças não somente no sentido de soberania, mas em relação às bases do Antigo Regime. Dentre eles, um dos mais enfáticos foi o deputado da Estremadura, Agostinho Freire:

[...] uma vez que lhe [isto é, ao Rei] se[ja] concedido o veto absoluto, devemos então arriscar-nos a que a ilustração, e as fadigas de 100 Homens escolhidos pela Nação sejam frustradas pelo simples querer de um só Homem? Diz o Rei que a Lei é má, e o Corpo Legislativo diz que a Lei é boa: qual será o resultado? Se o Rei insiste em que a Lei não seja executada, que resta logo à Nação? Sem dúvida, nenhuma outra cousa senão uma Revolução. Tal é o resultado do Veto absoluto demonstrado pelos melhores publicistas. Um Rei é um Homem, e um Homem erra, um homem tem paixões. A pessoa do Rei é inviolável, é de família escolhida, mas é de família de homens; é pois preciso que o Rei se não envergonhe de ceder aos votos da Nação ${ }^{8}$.

É apresentada aqui uma concepção típica das Luzes: o rei, uma vez que humano, suscetível aos erros das paixões, não poderia sobrepor-se à Nação, entidade abstrata, ainda que encarnada no "Corpo Legislativo", conjunto de cem homens por ela escolhidos. Mais do que a fragilidade da figura do rei, agora humanizado, Freire ataca diretamente o sistema com veto absoluto, que outrora colocava-se como completamente aceitável (e mesmo então não seria necessariamente absurdo, considerando, por exemplo, a sua aplicação na constituição do Brasil de 1824). Não só a representatividade de 100 homens eleitos é posta com plena superioridade à representação tradicional do rei, que é "apenas um homem", como a oposição entre elas serviria muito mais como combustível para "revoluções" do que para um funcionamento equilibrado entre executivo e legislativo. Por fim, o deputado se refere ao abstrato "melhores publicistas", que teriam chegado à esta mesma conclusão, lhe conferindo legitimidade.

${ }^{8}$ DIÁRIO das Cortes Geraes e Extraordinárias da nação portuguesa (1821-1822). Lisboa, 26.02.1821, p.157. 
A mescla realizada por Agostinho Freire entre uma argumentação lógica, que antepõe causa e consequência, com o argumento de autoridade resulta em um artifício discursivo que visava atacar a proposta de artigo à qual ele se contrapunha. Por fim, o deputado recorre a uma noção que perpassará todo o pensamento vintista: a de revolução. Embora associados pela historiografia como atores de um movimento revolucionário, que deu início a derrocada do absolutismo em Portugal, em geral, a "revolução" aparece como algo a ser evitado e, por vezes, rejeitado. Agostinho Freire, embora defensor radical do ideário liberal, encontra na própria instabilidade "revolucionária" o ponto de suporte para argumentar contra a pauta mais conservadora do voto absoluto, que dotaria o rei de importante papel no exercício da soberania - principal alvo de disputas à época.

A relação do monarca com a soberania foi compreendida de diversas formas. A historiadora Luísa Rauter Pereira, ao discutir o verbete "soberania", no Léxico da história dos conceitos políticos do Brasil, demonstra que, na primeira metade do XVIII, o poder real era apresentado como advindo de um "pacto primordial”. Isto é exemplificado através das reivindicações da "nobreza da terra" pernambucana, que, ao expulsar os invasores holandeses, teria estabelecido um pacto com D. João IV. O descumprimento deste daria o direito de rebelião. Daí se deriva uma noção de soberania que retornaria "aos povos", pois somente como soberanos eles teriam o direito de se rebelar contra o rei ${ }^{9}$. Esse entendimento se insere na concepção corporativa do poder, desenvolvida pela segunda escolástica, tomando por base os escritos de São Tomás de Aquino, sendo predominante em Portugal até o século XVII, perdurando ainda com força no século seguinte. Partindo de suas premissas:

O Estado se originaria de um "pacto social", através do qual o povo, enquanto comunidade, detendo o poder derivado de Deus, buscaria realizar o "bem comum", definido em consonância com os fins eternos do homem, fins estes que, por sua vez, pertenceriam à jurisdição da Igreja. Deste modo, em última instância, o Estado teria como fim o bem comum, tornando-se ilegítimo se o esquecesse, violando o direito natural e, com isto, o divino. Nestes casos, nas situações em que existisse tirania, São Tomás admitia o direito do "povo", da comunidade, de resistir ativamente, mas não o tiranicídio. ${ }^{10}$

\footnotetext{
${ }^{9}$ PEREIRA, Luisa Rauter. Soberania. In: JÚNIOR, João Feres (Org.). Léxico da história dos conceitos políticos do Brasil. $2^{\mathrm{a}}$ ed. rev. e ampl. Belo Horizonte: Editora UFMG, 2014, p. 403.

10 VILlALTA, Luiz C. Reformismo Ilustrado, censura e práticas de Leitura: Usos do Livro na América Portuguesa. Tese de Doutorado. Universidade de São Paulo, 1999.
} 
Essa concepção fortalecia o papel do povo, como comunidade, dando-lhes poder perante o monarca, uma vez que o pacto entre eles daria origem ao Estado. Além disso, ampliava a ação do papado, instituição mais próxima desse poder derivado de Deus, concepção, contudo, sujeita a críticas por parte dos neoescolásticos ${ }^{11}$. Entretanto, a política pombalina, a partir de meados do XVIII, combateu essa tradição pactuária. Para isso, reafirmou os direitos das jurisdições locais, dos corpos do reino e, por fim, um entendimento da soberania real "medida pela aceitação dos povos e da Igreja". Distanciava-se do tomismo neoescolástico na medida em que esse poder teria sido alcançado "pelos direitos de conquista, doação e sucessão e pelo ordenamento natural e divino, que fazia da soberania una e indivisível do rei a mais apropriada forma de organização do mundo humano" $"$.

A partir dessa digressão teórica, percebe-se que a fala de Agostinho Freire joga por terra a concepção pombalina, incompatível com os ideais que, desde o movimento do Porto, ocuparam os centros de poder em Portugal. Embora propugnassem uma regeneração de supostas tradições portuguesas, pautadas no pacto fundacional das míticas Cortes de Lamego, os vintistas inauguravam algo novo. $\mathrm{O}$ rei era agora um homem, passível de erros. Ao mesmo tempo, a origem divina da soberania, sustentada pela teoria corporativa do poder, não era mais suficiente. Os liberais do século XIX desejavam a soberania completa que pertencesse, para alguns, diretamente ao povo e, para outros, à nação ${ }^{13}$. Essa confusão deriva da emergência de uma reconfiguração desse povo, que ganhou força a partir de 1820: o povo-cidadão ${ }^{14}$. Embora as noções de Antigo Regime que ligam essa categoria à condição de súdito ou como Terceiro Estado não tenha desaparecido, elas perdiam espaço gradativamente. Os liberais que assumiram o governo em Portugal deveriam, então, elaborar uma Constituição que desse conta de articular o poder soberano com esse corpo político chamado "Povo" português.

Essas transformações podem ser observadas no trabalho parlamentar. Ao fim da sessão de 26 de fevereiro de 1821, ficou decidido, por 59 votos contra 26, que o sistema

\footnotetext{
${ }^{11}$ Cf: VILLALTA, Luiz C. El-Rei, os vassalos e os impostos: concepção corporativa de poder e método tópico num parecer do Códice Costa Matoso. Varia História, Belo Horizonte, v. 21, p. 222-236, 1999 b.

12 PEREIRA, Luisa Rauter, 2014, p. 404.

${ }^{13}$ Essa divergência diz respeito, sobretudo, à questão da representação e da autonomia dada aos representantes. A primeira, ente ndida como pertencente ao povo, privilegia a ação direta dos indivíduos em conjunto, seja através de assembleias populares abertas, abaixoassinados, seja através das armas. A segunda, concentra o poder nos representantes eleitos pelo povo ou, mais especificamente, pelos cidadãos.

${ }^{14}$ PEREIRA, Luisa Rauter, 2014, p. 180.
} 
adotado deveria ser formado por apenas uma câmara. $\mathrm{O}$ veto absoluto foi rejeitado por 78 deputados, contra sete favoráveis. Por fim, 81 deputados defenderam o voto suspensivo e apenas quatro foram contrários a qualquer espécie de veto ${ }^{15}$. Tais números expressam o caráter moderado que predominou em Lisboa. As posições mais radicais, como o veto absoluto ou a ausência de veto, foram maciçamente rejeitadas. O único modelo de controle do poder legislativo que provocou uma divergência significativa entre os deputados foi o bicameral, defendido como um meio termo que não daria tantos poderes ao executivo, representado na figura do rei, mas evitaria alegações de concentração de poderes em uma única instância. Barreto Feio, deputado alentejano, faria questão de exclamar contra essa possibilidade, explicitando "contradições" que ele acreditava derivarem de tal divisão do legislativo:

Senhores. - Não há muito que este Augusto Congresso declarou por um Decreto, que nele reside a Soberania. Este mesmo Congresso no Art. $18^{16}$ das Bases da Constituição reconheceu, e decretou a Soberania da Nação. (...) bem longe estava eu de supor que no seio desta Assembleia houvesse quem duvidasse e dela; mas, com suma admiração minha, vejo que não falta entre nós quem pertencia [sic]sustentar: que a Soberania reside não só no Congresso; mas n'outro Corpo, a que se deu impropriamente o nome de Conselho d'Estado, ultrajando-se assim a Majestade do Povo Português, e usurpando-se lhe a metade da Soberania; e com maior espanto vi, que se admitiu a discussão uma tão absurda proposta. Que contradição, Senhores! Que se dirá de nós? Como esperamos ter a confiança pública, se não temos firmeza nas nossas resoluções? E quando concluiremos a nossa Constituição, se, como Penélope, desfazemos num dia o que fizemos noutro? Uma segunda Câmera! [...]. ${ }^{17}$

Com esse inflamado discurso, repleto de surpresas, admiração, ultrajes, espantos e questionamentos, o deputado português abusa dos artefatos de elocução, mesclando-os com a comparação pautada na literatura clássica, representada pela personagem de Penélope, esposa do protagonista da Odisseia, de Homero, intercalando seus argumentos entre a erudição e a força das exclamações, indo muito além da argumentação puramente lógica $^{18}$.

\footnotetext{
${ }^{15}$ DIÁRIO, 26.02.1821, p. 165.

${ }^{16}$ As discussões que se seguiram fizeram com que o conteúdo que se fazia presente no artigo $18^{\circ}$ das Bases passasse a ser expresso no artigo $20^{\circ}$ destas.

${ }^{17}$ DIÁRIO, 26.02.1821, p. 157.

${ }_{18}$ Aqui, dialogo com José Murilo de Carvalho, segundo o qual a retórica: "exige uma grande variedade de argumentos de natureza não-lógica. Em muitos casos, mesmo na presença de elementos suficientes de convencimento, é necessário o recurso à retórica, pois o convencimento pode não ser suficiente para levar à ação". Cf. CARVALHO, José Murilo de. História Intelectual no Brasil: A retórica como chave de leitura. Topoi. n.1, p. 123-152. Jan./Dez., 2000.
} 
Essas disputas levaram a formulação da seguinte questão: a soberania pertence à Nação, mas quem é esta Nação, o que a define? A resposta variará de acordo com o momento em que é feita a pergunta, a quem é feita e, ainda assim, não terá forma unívoca. José Carlos Chiaramonte explora essa dificuldade e propõe:

Trata-se de um caminho diferente do que começa com uma definição prévia de nação. Este último ponto de partida [...] circunscreve a análise numa visão apriorística da história das nações. Ou seja, trata-se de uma condição que não auxilia a compreender nem a substância do que, em cada momento, os protagonistas entendiam ao empregarem o conceito nem, igualmente, as diversas modalidades dos conglomerados humanos e/ou organismos políticos que, em cada momento, foram considerados como nações. ${ }^{19}$

Sua crítica se dirige aos trabalhos que buscam uma definição de nação anterior e, portanto, generalista, o que acabava por deixar brechas em análises que pretendem tratar de casos específicos. Chiaramonte se interessa pela compreensão do que cada protagonista entendia por nação e pela substância das "diversas modalidades dos conglomerados humanos e/ou organismos políticos que, em cada momento, foram considerados como nações”. Partilhando desse interesse buscar-se-á não uma definição prévia da nação, mas aquela que se fazia presente no contexto em análise.

\section{A NACÃO PORTUGUESA ENTRE DISCURSOS E PRÁTICAS}

Para isso, será necessário estabelecer alguns parâmetros básicos. O primeiro passo será identificar o que os deputados reunidos nas Cortes Gerais chamavam de Nação Portuguesa. É em nome dela que eles agem, é para ela que se estabelecerá uma constituição política. Esta, contudo, será uma acepção institucionalizada da nação, definida por um artigo de lei, que tentará direcionar um entendimento que, na prática, é concebido e utilizado de diversas maneiras, em diferentes discursos. Ressalta-se ainda que, embora o caráter "português" seja o foco, não se deve perder de vista a nação "brasileira", "brasílica", "brasiliense”, mesmo que concebida de maneira embrionária.

${ }^{19}$ CHIARAMONTE, José Carlos. Metamorfoses do conceito de nação durante os séculos XVII e XVIII. In: JANCSÓ, István (Org.). Brasil: Formação do Estado e da Nação. São Paulo: Hucitec; Ed. Unijuí; Fapesp, 2003, p. 64. 
As Bases da Constituição da Monarquia Portuguesa definem, em seu artigo $16^{\circ}$, que: "A Nação Portuguesa é a união de todos os Portugueses de ambos os hemisférios"20. Apesar de concisa, esta definição já fornece direções importantes. Primeiramente, a Nação não se refere diretamente aos indivíduos, mas à união destes, como uma comunidade. Seus componentes não são explicitamente os cidadãos, mas os portugueses, não sendo definido quem seriam esses últimos. Por fim, afirma que a qualidade de "ser português" não se limita aos pertencentes à porção europeia, incluindo "ambos os hemisférios", deixando claro que o Brasil fazia parte daquele projeto constitucional.

A aprovação deste artigo se deu sem qualquer discussão ou discordância, do que se pode inferir que, para as pretensões que guiaram os elaboradores das Bases, esta definição foi considerada, por unanimidade, suficiente. Portanto, a Nação Portuguesa diria respeito ao todo dos portugueses, independentemente das fronteiras territoriais internas aos domínios da Coroa. Ressalta-se, entretanto, que nesse momento não se encontrava presente nenhum deputado eleito pelas províncias do Brasil, o que geraria diversos desentendimentos posteriores, posto que muitos deputados eleitos no ultramar questionariam a real representatividade que possuíam no processo constituinte.

Essas mesmas Bases em seu texto introdutório evidenciam que, mesmo representando a "união dos portugueses de ambos os hemisférios", irão tratar dos direitos individuais do cidadão, organizar e limitar os poderes políticos do Estado:

As Cortes Gerais Extraordinárias e Constituintes da Nação Portuguesa, antes de procederem a formar a sua constituição política, reconhecem e decretam, como bases dela, os seguintes princípios, por serem os mais adequados para assegurar os direitos individuais do Cidadão, e estabelecer a organização, e Limites dos Poderes Políticos do Estado ${ }^{21}$.

Ainda que fique de fora do artigo das Bases que define a Nação Portuguesa, seu teor intimamente político é exposto desde a abertura do texto. É a Nação que, através das Cortes, define e organiza o Estado português e estabelece os direitos dos cidadãos como indivíduos. Assim, através de um documento, a Nação, por meio de seus representantes

\footnotetext{
${ }^{20}$ PORTUGAL, 1821.
}

${ }^{21}$ PORTUGAL, 1821. 
reunidos nas Cortes, autodefine-se, estrutura o Estado e garante os direitos básicos daqueles que irão compor o seu corpo político: os cidadãos. Não se trata aqui de criar, dotar de existência, nenhum desses três elementos, mas defini-los, estabelecer seus claros limites e funções. Para os deputados reunidos em Cortes, a nação portuguesa já existia, sendo eles próprios, durante o exercício de seus encargos, a sua corporificação possível, por meio de representatividade. Escapa, contudo, apesar do intricado trabalho de autodefinição presente na documentação legislativa, uma definição elementar para o entendimento da Nação: quem seriam esses portugueses que, unidos, formariam a Nação?

Deixada de lado nas Bases, essa questão seria logo colocada, pois, no dia 08 de março, foram discutidos os artigos que comporiam a Constituição propriamente dita. Em resumo, pode se dizer que, em uma primeira versão, houve uma distinção entre ser português e ser cidadão, diferença que, após longas colocações, foi extinta, ficando definido no artigo $21^{\circ}$ que "todos os portugueses são cidadãos", sendo, a partir daí, detalhados aqueles que gozariam desta qualidade de "português cidadão".

A equivalência entre o ser português e o ser cidadão, porém, deixou arestas, uma vez que nem todos englobados no conjunto da Nação portuguesa foram contemplados com os mesmos direitos políticos. Essa diferenciação é fruto e, ao mesmo tempo, origem das contradições que surgiam nesse momento de transformação de paradigmas. Embora os conceitos mantenham parte de sua carga histórica, a ascensão de ideais liberais, em detrimento daqueles típicos do Antigo Regime, levou a quebra do entendimento acerca do "pertencer à nação portuguesa", concepção que reconfigurava os projetos políticos que concorriam pela proeminência não somente nas Cortes, por todo o mundo luso-brasileiro.

Outra perspectiva útil é apresentada pelo Vocabulário Portuguez e Latino, de 1728, escrito pelo padre Raphael Bluteau, que definia a nação como "nome coletivo, que se diz da Gente, que vive em alguma grande região ou Reino, debaixo do mesmo Senhorio. Nisto se diferencia nação de povo, porque nação compreende muitos povos"22. A nação, portanto, designava um grupo de súditos de um mesmo soberano, uma vez que dizia respeito àqueles "debaixo do mesmo senhorio", como foi destacado anteriormente, quando se identificou uma relação umbilical entre monarquia-soberano e nação, sob o Antigo Regime. Esse grupo poderia ser composto por diferentes povos. Apesar da ênfase

${ }^{22}$ BLUTEAU, Raphael. Vocabulário português e latino. Coimbra: Real Colégio das Artes da Companhia de Jesus, 1728, p. 658. 
ao mesmo "senhorio", ou seja, ao rei, a nação era associada também ao compartilhamento de etnias, castas, a uma mesma língua, ascendência ou origem comum e mesmo costumes, que deveriam ser partilhados pelo monarca ${ }^{23}$.

Essa noção começou a perder força de maneira acintosa com o vintismo, embora não tenha sido abandonada. A primeira diferenciação, em uma perspectiva luso-brasileira, pode ser observada anteriormente: se a nação dizia respeito àqueles que viviam em algum Reino, desde 1815, havia uma especificidade. Sendo o Brasil elevado à categoria de Reino Unido, este poderia ser entendido como uma Monarquia compósita, um conjunto de reinos, todos submetidos a um mesmo monarca. Em partes, poderia se entender que tal nação seria formada, segundo a concepção do Antigo Regime, por súditos que viviam em diferentes reinos - sendo essa a primeira mudança. Tal característica é marcada pela peculiaridade da transferência da família real que, anteriormente, já provocara um novo rearranjo, uma vez que, desde 1808, aqueles que antes eram submetidos diretamente ao Príncipe D. João em Portugal passaram a ser governados a partir do Rio de Janeiro e com forte interferência dos ingleses, que auxiliaram os portugueses no combate às tropas napoleônicas. Porém, ainda que algumas rupturas se colocassem, permanecia, em última instância, a submissão dos três reinos ao mesmo monarca.

Marco Pamplona, ao escrever o verbete "Nação", também para o Léxico, ressalta que: "O léxico não nos permite a percepção do embate mais vivo, captar todas as intenções que a fala em ato carrega, com sua intencionalidade e emoção, e que, num ou noutro momento específico, sofre transformações" ${ }^{24}$. Sabendo disso, busca analisar, dentro das "comunidades argumentativas específicas" (debates em jornais, constituintes e assembleias), as mudanças do conceito através de atos de fala articulados em discursos políticos. Essas transformações estabelecem uma relação dual com os atores que as vivenciam, pois, ao mesmo tempo em que direcionam o processo de construção e expressão de suas ideias, são também resultado dos usos feitos por essas pessoas.

A diferenciação ou modulação do vocabulário é elemento vital para a atuação tanto dos sujeitos históricos que, buscando semelhanças e distinções, reforçam ou alteram suas posições e ampliam suas possibilidades de ação, quanto por parte dos historiadores

\footnotetext{
${ }^{23}$ BLUTEAU, 1728, p. 665.

${ }^{24}$ PAMPLONA, Marco A. Nação. In: JÚNIOR, João Feres (Org.). Léxico da história dos conceitos políticos do Brasil. $2^{\mathrm{a}}$ ed. rev. e ampl. Belo Horizonte: Editora UFMG, 2014, p. 144.
} 
que, observando esse processo, encontram diferentes perspectivas para a realização de seu trabalho. Márcia Regina Berbel, atenta a essas modulações, identifica grupos políticos que teriam no entendimento do que seria a nação portuguesa um ponto de articulação. No que diz respeito aos deputados eleitos pelas províncias de Portugal, sobretudo no período anterior à chegada das deputações do Brasil, Berbel distingue "duas grandes alas":

\begin{abstract}
Os conservadores, representados pelos deputados Pinheiro de Azevedo, Trigoso e Camelo Fortes, [que] procuraram de diversas formas diminuir os poderes do Parlamento. Defenderam o veto absoluto do rei, a formação de um Conselho de Estado [...] e a formação de duas Câmaras para a composição do Parlamento. Na defesa da soberania do Congresso, configurou-se uma coalizão entre os diferentes grupos liberais. Fernandes Tomás, do Porto, e Borges Carneiro, de Lisboa, [que] defenderam o direito ao veto suspensivo do rei e o sistema de Câmara única para as funções do Legislativo, e foram vitoriosos. ${ }^{25}$
\end{abstract}

Essa categorização além de fornecer parâmetros para a compreensão dos discursos de cada um desses personagens, torna evidente a heterogeneidade das Cortes. Embora fruto de um movimento autodenominado liberal, seu conjunto estava longe de abarcar uma concepção única de liberalismo. Havia, por exemplo, ainda que nunca de maneira explícita, aqueles mais próximos a uma política conservadora, como bem aponta Berbel. Não se deve confundir, contudo, a pauta dos "conservadores" com a defesa do absolutismo. Embora, por vezes, sejam acusados de defensores do Antigo Regime, esses jamais se definiram desta forma. Os deputados em Cortes, pelo próprio pressuposto do lugar que ocupavam, identificavam-se todos como liberais, termo que se torna um "guarda-chuva", abarcando posicionamentos muitas vezes diametralmente opostos.

Outro caminho para compreendermos a postura dos deputados nos embates constituintes foi proposto por Valentim Alexandre ${ }^{26}$. Para o historiador, Borges Carneiro, deputado pela Estremadura e um dos líderes do vintismo liberal a partir de Lisboa, seguiria, no tocante à articulação das várias partes da Nação, uma postura conciliadora. Por outro lado, Fernandes Tomás, deputado beirão, líder do Sinédrio da Revolução do Porto, representaria, por sua vez, o integracionismo. No âmago dessa divergência está

\footnotetext{
${ }^{25}$ BERBEL, Márcia Regina. A nação como artefato: deputados do Brasil nas Cortes Portuguesas - 1821-1822. São Paulo: Hucitec: Fapesp, 1999, p. 53.

26 ALEXANDRE, Valentim. Os sentidos do Império - questão nacional e questão colonial na crise do Antigo Regime português. Porto: Afrontamento, 1993.
} 
não somente uma compreensão diferente da soberania, mas, principalmente, das práticas que daí seriam derivadas. Carneiro defendia a concessão de uma autonomia limitada ao necessário para que não se perdesse definitivamente o vínculo entre os Reinos ${ }^{27}$. Tal postura derivava de uma perspectiva a partir da qual a união entre Brasil e Portugal seria vital em ambos e, por isso, o exercício da soberania por parte das Cortes em Lisboa poderia ser mais flexível, possibilitando, por exemplo, o estabelecimento de altos cargos do executivo no continente americano.

Embora o termo "conciliador" transmita a impressão de uma postura mais pacífica, são agrupados nessa linha justamente aqueles deputados que defenderiam de forma mais resoluta o reforço de ações militares no Brasil. Entre junho e julho de 1821, os votos "conciliadores" iriam no sentido do envio de mais tropas portuguesas ao Rio de Janeiro. Por outro lado, aqueles que entendiam a nação como um corpo integral, que deveria manter sua soberania centralizada, como Fernandes Tomás, fizeram oposição à intervenção militar, defendendo uma adesão diplomática, pacífica, das províncias do Brasil $^{28}$. De qualquer maneira, venceu o envio das tropas, resultado de uma postura que, apesar de maleável em seu ideal de soberania, mostrava-se inflexível diante da possibilidade de perder por completo o controle do território americano.

Um ano depois, uma situação semelhante se colocava, porém, em ambiente muito mais tenso. Ao debaterem um artigo que propunha a sujeição dos comandantes das forças $\operatorname{armadas~às~juntas~militares~}^{29}$, disse Borges Carneiro:

\begin{abstract}
As sucessivas notícias do Brasil têm levado as cortes a tal evidência, que já se não pode sustentar, o que se escreveu quando se fez o presente artigo. É preciso falar claro, e tomar diversa marcha: no Brasil geralmente falando não há ainda aquela civilização que supõe o sistema constitucional. Eu disse aqui em outra ocasião, que poderia chegar o tempo de ser necessário mandar a alguma parte do Brasil algum cão de fila ou um leão: isto era, se a experiência mostrasse que o emprego dos meios liberais, civis, e constitucionais em vez de gerar o afeto do Brasil, produzia o contrário efeito, de os facciosos de alguma província se ensoberbecerem com isso, e erguerem contra Portugal um colo altivo e ingrato. Eis o que se está verificando em o Rio de Janeiro. ${ }^{30}$
\end{abstract}

\footnotetext{
${ }^{27}$ CASTRO, Zilia Osório de. Cultura e Política: Manuel de Borges Carneiro e o Vintismo. Volume 1. Lisboa: Instituto Nacional de Investigação Científica/Centro de História da Cultura da Universidade Nova de Lisboa, 2014, p. 341.

${ }^{28}$ BERBEL, 1999, p. 95.

${ }^{29}$ Artigo $5^{\circ}$, projeto 232, que trata das relações entre Brasil e Portugal: "Que o comandante da força armada de cada uma das pro víncias fique subordinado à junta provincial, da qual porém será membro nato, com voto somente na parte militar” (DIÁRIO, 22.07.1822, p. 889).

${ }^{30}$ DIÁRIO, 22.07.1822, p. 890.
} 
O Rio de Janeiro, onde estava D. Pedro, ocuparia papel central nas articulações "separatistas" que, segundo Borges Carneiro, deveriam ser contidas a qualquer custo. A defesa enfática de uma ação militar era resultado de um entendimento que via na manutenção dos laços entre os reinos algo primordial. Por esse motivo, o ideário “conciliador", aceitava a criação de uma ou mais delegações do poder executivo no Brasil, facilitando a resolução de assuntos administrativos e judiciais que, sem tal medida, exigiriam uma viagem a Lisboa $^{31}$.

Chama a atenção o argumento civilizatório, recorrente no tocante às relações lusobrasileiras. Borges Carneiro, ao defender o envio de "cão de fila ou um leão", metáfora que utilizara em sessão anterior, de 22 de maio de 1822, autorizava o combate, o uso da força como imperativo, na medida em que "facciosos, rebeldes, anarquistas" atuassem no Brasil. A existência dessas minorias perturbadoras da ordem - muitas vezes associadas à incivilidade - foi um dos principais argumentos legitimadores da intervenção militar, que seria defendida também por Moura. Em uma fala de grande virulência, quando elaborava seu discurso contra o artigo $5^{\circ}$, que buscava submeter o chefe de armas à Junta de Governo, o deputado português retomou a discussão anterior sobre o envio de tropas, defendido em três pontos:

Nem também é verdade que ela [a desorganização] exista no coração de todos os Americanos: e por conseguinte qual será e [sic] politico; qual será o filantropo, que rejeite a intervenção da força para se conter, e se debelar no seu principio uma opinião que a vontade geral não abraça: opinião que todos os Americanos com poucas exceções julgam perigosa, subversiva, prejudicial á tranquilidade publica, e até injusta. Eis-aqui o primeiro destino da força enviada a um pouco da América. ${ }^{32}$

O primeiro fator que justificaria o envio de tropas para o Brasil seria então o caráter subversivo de uma minoria. Alguns aspectos merecem ser detalhados nesse ponto. Primeiramente, Moura recorre a um discurso muito próximo do discurso "jacobino", no qual a vontade geral deve predominar acima das vontades particulares, ainda que pelo uso da força e da violência. Embora o léxico "jacobino" tenha adquirido forte carga negativa entre os vintistas portugueses e a associação explícita aos seus ideais tenha sido rejeitada, a influência da Revolução Francesa e, inclusive, de boa parte daquilo que foi

\footnotetext{
${ }^{31}$ DIÁRIO, 22.05.1822, p. 223.

${ }^{32}$ DIÁRIO, 22.07.1822, p. 894. Grifo do autor.
} 
associado aos jacobinos, marcou profundamente o vintismo ibérico. Destaca-se o que diz respeito à essencialidade do pertencimento da soberania da nação e de sua indivisibilidade. O controle e o centralismo, alegadamente em prol do público, germinavam. O uso de noções de totalidade, contrapostas às exceções, complementa a vontade geral, de forma que toda dissensão não só é colocada em segundo plano, como também é passível de ser eliminada. Na sequência, Moura aproveitou a dicotomia "Europa versus América" para validar seu segundo ponto:

O segundo é proteger a propriedade real e pessoal dos muitos Europeus nossos irmãos, que ali [na América] tem desenvolvimento [sic] o espírito de indústria. Quem duvida que uma preocupação antiga e delirante, que uma antipatia entre Europeus e indígenas exacerbadas agora no meio de convulsões anarquias, bem afiada a espada da vingança, e põe em risco a segurança de milhares de Portugueses europeus nossos irmãos? E havemos nós deixá-los expostos a bárbara e indisciplinável ferocidade de uns poucos de negros e mulatos? Os fatos falam de [...], e são públicos: e até quando havemos nós fechar os olhos aos clarões de uma quotidiana experiência! Pernambuco tem-se despovoado: de Pernambuco e do Rio de Janeiro centos e centos de Portugueses europeus proprietários tem abandonado as suas casas, os seus engenhos, as suas plantações, as suas famílias, os seus parentes, e os seus amigos; tem-se acolhido nas ilhas, e em Lisboa, fugindo á desordenada cobiça, e ao ódio inveterado daquelas raças degeneradas. [...] Crimes públicos, crimes particulares assaz nos atestam, quão arriscada está ali à vida, e a fortuna de tantos Portugueses Europeus, que não tem outro delito, senão o de terem para ali transportado os seus cabedais para promoverem a agricultura, para verificarem a indústria, e para civilizarem o país. E será impolítico, será injusto, será contra os deveres da filantropia empregar a força para proteger cousas tão sagradas, e para obstar ao desenvolvimento de paixões tão perigosas! Pois este foi o motivo da nossa opinião para que a força fosse ali empregada com o destino de proteger uma tão sagrada causa; sim uma força; toda a força de que o Governo possa dispor há de ser ali empregada, e desenvolvida neste sentido com toda a energia, e com todo o vigor. ${ }^{33}$

Há nessa fala uma clara tentativa de diferenciação, detração e apagamento do outro. Ao dizer "portugueses", Moura os adjetiva como europeus. Essa era uma designação comum nas Cortes para diferenciar o local específico de nascimento, uma vez que, como se disse, em suas Bases, define-se a nação como a união dos portugueses de ambos os hemisférios. Contudo, o deputado deixa apenas implícita a existência de outras "variedades" de portugueses. Enquanto o adjetivo "europeu", complementa o português, tratando esses como "irmãos", "industriosos", o "americano", em nenhum momento, é associado ao português. Muito pelo contrário, a América é relacionada com "indígenas", que antipatizam com os europeus, movidos por vingança. A presença de "pretos e mulatos" tornaria o continente americano terra de "bárbaros", "ferozes", “indisciplinados", que não possuíam civilização, pois eram "raças degeneradas". Caberia às Cortes socorrer os europeus que civilizavam "o país", proteger a "sagrada causa" dos "filantropos portugueses europeus" das "paixões tão perigosas" desenvolvidas pelos americanos. Moura

${ }^{33}$ DIÁRIO, 22.07.1822, p. 895. 
fazia coro aos dizeres de Borges Carneiro, o estatuto de português daqueles nascidos no continente americano é apagado. Eles são contrapostos aos "portugueses europeus", em uma dicotomia da civilização versus selvageria, em que aquele que não é europeu é degenerado e, por isso, deve ser combatido.

Em resumo, esses discursos reforçam a vontade geral, a proteção aos portugueses europeus e às suas propriedades, ao mesmo tempo em que é defendida a necessidade de se conter uma "inevitável" revolta escrava. Articulam-se desse modo os componentes de um discurso civilizatório que legitima o uso da violência, da força militar, para garantir o vínculo entre as duas porções do Império Português. Em última instância, há nessas falas uma hierarquização que, ao diferenciar e opor os habitantes de um e outro continente, destoa dos princípios explicitados nas Bases Constitucionais que buscam equalizar todos os que seriam portugueses.

Este será um dos maiores desafios para o entendimento entre representantes de um e de outro lado do Atlântico, que, por vezes, tomou proporções extremas, com acusações de um suposto desejo recolonizador por parte dos europeus e de independentismo pelos americanos. São notáveis as tentativas de elaboração de discursos que conciliem os ideais liberais, como a livre escolha dos povos, com a opinião particular daquele que os realiza. O próprio encerramento da fala de Moura se encaixa nisso:

Entretanto, se toda a América assim o deseja, as benções do céu se entornem sobre a sua obra; a minha filantropia estremecera [sic] quando eu duvidasse, que tão grande bem lhe acontecesse. Estou sim persuadido, que na América não existem duzentos capazes de tão grande desenvolvimento. Na América, segundo eu penso, há só terra, e vegetação; o homem falta; a espécie é pouca; há pouca civilização, muita depravação moral; mas ambição, e vaidade há montes. O tempo dará razão a quem a tiver. ${ }^{34}$

Após um longo pronunciamento justificando a ação de tropas europeias no ultramar, mas que deveria versar sobre a aprovação da relação entre o chefe das armas e a junta de governo, o que se vê é um encerramento que admite a separação do Brasil território reduzido apenas a sua natureza. Considerando que, assim como Borges Carneiro, Moura defendeu a intervenção militar enfaticamente, não seria de todo incongruente associá-lo à vertente "conciliadora" que, ao contrário dos “integracionistas", via no uso da força uma alternativa válida para garantir a ordem nas províncias americanas. Apesar da aceitação do uso de violência, a "conciliação" implicava o atendimento de algumas reivindicações das províncias ultramarinas para garantir a união. $\mathrm{O}$ que se percebe na última passagem é, justamente, uma nova mobilização da vontade geral que, uma vez decidida pela separação, deveria, supostamente, ser obedecida.

${ }^{34}$ DIÁRIO, 22.07.1822, p. 895. Grifo do autor. 
Não se deve, porém, confundir isso com uma aceitação passiva ou de bom grado. Tanto o contexto interno do discurso, quanto o externo demonstram isso. Anteriormente, Moura alegara que essa divisão seria mais prejudicial ao Brasil, que deixaria de pertencer ao "sistema europeu" e sofreria com "anarquias e convulsões populares", enquanto Portugal perderia apenas parte de sua "consideração política". Suas últimas frases constroem um panorama extremamente negativo da América e qualquer possibilidade de relações amistosas é ignorada, deixando aquela porção ao sabor dos desdobramentos do tempo. Além disso, todos os indícios de desejo de independência são secundarizados, associados à ação de facções e minorias indignas. Portanto, a alegada aceitação da vontade geral acaba restrita ao campo do discurso, sendo, nele mesmo, desencorajada através de uma série de questionamentos e características negativas em relação à América e seus habitantes.

Já foi ressaltado que, embora a divergência entre "conciliadores" e "integracionistas" fosse sobretudo quanto à radicalidade de um ideário, ela tinha consequências práticas. Seguindo a proposta historiográfica que mobiliza essas categorias, a fala de Carneiro foi selecionada para exemplificar esse entendimento mais maleável da soberania, aberto a concessões, mas que leva ao limite o esforço, entre a parcela europeia dos deputados, de garantir a união. A fala de Moura, ao se debruçar exaustivamente sobre a defesa da intervenção militar, direciona o ouvinte/leitor justamente nesse sentido. Contudo, a aceitação, ainda que a contragosto, da perda do território americano como decorrência da manifestação da vontade geral de um povo supostamente composto em grande medida por diminutos e incivilizados homens, torna seu discurso incoerente com o ideário de uma linguagem "conciliadora", aproximandose mais do "integracionismo". Nesta linha, temos a fala de Fernandes Tomás, datada de março de 1822, que, levando a centralização e indivisibilidade da soberania nacional ao extremo, sintetizaria esse ideário "integral":

[...] mas agora dizer que devemos esperar por notícias ulteriores, a que fim? É isto pelos sustos que a Comissão concebeu? Se eles são justos, se o Brasil com efeito não quer unir-se a Portugal, como tem estado sempre, acabemos de uma vez com isto: passe o Sr. Brasil muito [bem], que cá nós cuidaremos de nossa vida. De duas uma ou o Brasil está de sorte que apesar das notícias que tem vindo não há alteração ou sossego dos povos (porque em quanto a haver descontentes em todas as partes os há) ou não: senão está de acordo, se realmente os povos do Brasil desejam verdadeiramente desunir-se de Portugal, 
eu declaro altamente que a minha opinião é que se desunam $(O$ ilustre Deputado foi repetidamente chamado à ordem por vários membros da Assembleia)..$^{35}$

Esse discurso do líder vintista ficaria conhecido por seus contemporâneos e, também, pela historiografia como "Adeus, Sr. Brasil", marcando o agravamento das tensões entre os dois hemisférios. Discutiam-se, então, as medidas que as Cortes deveriam tomar em relação ao parecer prestado pela Comissão Especial dos Negócios Políticos do Brasil $^{36}$ a respeito da Representação ${ }^{37}$, feita pela junta de governo de São Paulo, entregue a D. Pedro e levada às Cortes. $\mathrm{O}$ parecer indicava a necessidade de adiar-se qualquer resolução, haja vista a constante chegada de notícias que poderiam alterar o impacto que a Representação teria no Brasil. Boa parte dos deputados ultramarinos concordava com a prudência, uma vez que as decisões poderiam tornar-se inúteis ou piorar o quadro de insatisfações no continente americano.

Fernandes Tomás, contudo, faz valer sua caracterização como um radical: convicto de que a Nação deveria ser formada por um todo unido, afirma que, caso o Brasil não estivesse de pleno acordo com esta união, deveria se separar: cisões internas não poderiam ser admitidas. Esta fala não passou despercebida. A redação do Diário destaca, ao realizar o acréscimo entre os parênteses, a comoção que ela provocara. O chamamento à ordem seria frequente naquela assembleia. Com a função primeira de organizar os debates e garantindo que a ordem do dia fosse discutida, esse recurso não deixava de ser utilizado para cercear, interromper e atrapalhar a fala daquele que tinha a palavra. Embora não se deva confiar plenamente nos registros, a presença do advérbio "repetitivamente" e do pronome indefinido "muitos" não é comum no Diário, que geralmente inseria apenas o vocativo “Ordem!", o que permite inferir que Tomás provocara uma grande polêmica. Interrompido, retomou a palavra em seguida, respondendo:

\footnotetext{
${ }^{35}$ DIÁRIO, 22.03.1822, p. 583.

${ }^{36}$ Nomeada no dia 12 de março de 1822 , era composta por doze membros, sendo seis de Portugal e seis do Brasil, cada um oriundo de uma província, buscando dar a maior diversidade possível à Comissão. Seus membros foram Antônio Carlos (São Paulo), Custódio Gonçalves Ledo (Rio de Janeiro), Pinto de França (Bahia), Belford (Maranhão), Granjeiro (Alagoas) e Ignácio Pinto (Pernambuco) pelo Brasil, e Francisco Trigoso (Beira), Moura (Beira), Borges Carneiro (Estremadura), Annes de Carvalho (Alentejo), Pereira do Carmo (Estremadura) e Guerreiro (Minho) por Portugal.

${ }^{37}$ Documento que terá grande repercussão nos debates das Cortes, trata-se de um conjunto de representações escritas pelo governo, senado da Câmara e clero de São Paulo e enviado para o príncipe D. Pedro. Escrito na virada de 1821 para 1822, surgia como resposta sobretudo aos decretos de 29 de setembro, que, em linhas gerais, versavam sobre a formação e administração das províncias do Brasil, retorno do príncipe para a Europa e extinção dos tribunais do Rio de Janeiro. Não cabe, por ora, uma análise detalhada de seu conteúdo. Basta saber que nele se fazia explícita a acusação de um espírito colonizador das Cortes, que iludira os portugueses da América.
} 
Eu estou na questão, nem sei porque possa ser chamado a ordem; pois por ventura não, posso expressar a minha opinião? Por ventura se quer estabelecer a proposição contrária, isto é, que por força sejam unidas a Portugal as províncias do Brasil sem o quererem ser. Que é o que se quer, que fiquem em dúvida que o Congresso quer violentar o Brasil? Não: o Congresso não quer tal cousa. (Apoiado). Ou o Brasil quer estar ligado com Portugal, ou não quer. Se quer há de estar sujeito ás leis que as Cortes fizerem, senão desligue-se. Eu quero declarar assim francamente meus princípios para mostrar que eles não são princípios de opressão; para que não se me venha argumentar que aqueles homens tem uma força muito grande. Se essa força é para sustentar as suas ideias, então é porque não querem estar unidos com Portugal; e senão querem desliguem-se; este é o direito de todos os Brasileiros, e de todas as Nações (Apoiado). ${ }^{38}$

Alguns aspectos devem ser ressaltados nessa retomada de seu discurso. A radicalidade do deputado português pauta-se por uma visão firmemente embasada nos ideais liberais, dentre os quais, o da liberdade contra qualquer opressão e o respeito à Vontade $\mathrm{Geral}^{39}$. Dessa forma, ainda que inclua formalmente o Brasil na nação portuguesa, ao associar o direito de não subordinação à todas as nações e dizer que o Brasil tem esse direito, acaba por reconhecê-lo como uma nação própria, uma vez que detentora de soberania para se manter, ou não, unida à Portugal - brecha que será constantemente utilizada pelos brasileiros, que veem a unicidade da nação não como um dado, mas uma escolha, passível de contestação.

Outro aspecto marcante está no fato de que, enquanto sua primeira fala é interrompida por vários de seus colegas de Congresso, ao retomá-la e defendê-la, Fernandes Tomás consegue, como indicam os acréscimos da redação, o apoio dos presentes. Uma primeira leitura poderia causar estranhamento, uma vez que, praticamente em sequência, o mesmo deputado, tratando do mesmo assunto, teria sido vividamente repreendido para, logo em seguida, receber diversas manifestações de apoio. É preciso aqui fazer algumas considerações. Primeiramente, tais marcações não especificam com precisão quem são os que invocam o pedido de ordem ou o apoio, podendo ter origens em agrupamentos circunstanciais que, com certa fluidez, se opunham na assembleia portanto, não haveria necessariamente uma alteração de posição dos ouvintes, mas apenas preponderância de grupos diferentes. A volubilidade, contudo, não pode ser descartada, sendo inerente aos debates ocorridos oralmente. Isso porque envolve um processo

\footnotetext{
${ }^{38}$ DIÁRIO, 22.03.1822, p. 583.

${ }^{39}$ CASTRO, 2014.
} 
praticamente simultâneo de fala-recepção-compreensão-manifestação, o que, muitas vezes, resulta em manifestações imediatistas, uma vez que ocorrem antes da conclusão do raciocínio do orador. Por fim, não se deve ignorar que, de maneira geral, os deputados eram homens de grande erudição, com formação em retórica e oratória, o que lhes dava meios para, até certo ponto, manipular seu público. Considerando o reconhecido dom de Fernandes Tomás nesses aspectos, não é improvável que a polêmica causada em sua primeira fala tenha sido um mecanismo para chamar a atenção do público e reforçar seus pontos, mais claramente expostos na sua retomada.

É necessário ressaltar que as tensões entre Brasil e Portugal no momento focalizado, sobretudo nas Cortes, não estavam colocadas de modo evidente. A radical declaração feita por Tomás, que diz preferir a separação do Brasil caso essa fosse a vontade daquela porção do reino, apesar de partir da Representação realizada pela junta de governo de São Paulo, ignorava trechos explícitos no documento, que diz: "Mas nós, declaramos perante os homens, e perante Deus com solene juramento, que não queremos, nem desejamos separar-nos de nossos caros Irmãos de Portugal"40. Assim, o ônus da ruptura é passado para o Brasil, que teria seu suposto desejo respeitado pelos vintistas.

Sua retomada vai justamente nesse sentido, disfarçando a radicalidade de seus ideais, incompatíveis com uma descentralização da soberania nacional, com os princípios de não opressão e o respeito dos direitos de "todos os brasileiros e de todas as nações". Dessa maneira, a defesa de que o Congresso seria o único representante de direito da Nação foi reafirmado. A ampla aceitação da soberania nacional, portanto, é mobilizada para legitimar a inicialmente chocante proposta integracionista, conforme explicitado pelos “apoios" registrados no Diário ${ }^{41}$.

Essa mudança de estilo, primeiramente radical e depois moderada, foi percebida pelos demais deputados. O baiano Borges de Barros falou logo em seguida: "Modificada assim essa ideia, convenho; mas não a sofro do modo que foi apresentada anteriormente" 42 . Sua crítica se dá justamente ao estilo adotado por Tomás em sua primeira intervenção, questionando: “Que quer dizer 'Adeus Sr. Brasil'?”, em alusão ao

\footnotetext{
${ }^{40}$ REPRESENTAÇÕES que à Augusta presença de Sua Alteza Real, o Príncipe Regente do Brasil, levaram o Governo, o Senado da Câmara, e Clero de São Paulo; (...). Rio de Janeiro: Imprensa Nacional, 1822, p. 13.

${ }^{41}$ Deve-se ressaltar que havia entre os próprios deputados, denúncias de que os registros do Diário seriam incompletos ou mesmo tendenciosos. Diante dessa hipótese, mesmo que não se possa afirmar a efetiva predominância de um apoio, o Diário, sendo um órgão oficial, teria escolhido legitimar essa posição, o que já nos indica uma tendência na disputa de forças no interior das Cortes. ${ }^{42}$ DIÁRIO, 22.03.1822, p. 583.
} 
"Passe o Sr. Brasil muito [bem]", dito pelo português logo antes. Esse discurso, que evidencia o radicalismo integracionista, é, em seguida, aproximado pelo baiano ao presente na Representação de São Paulo, extremamente criticada e alvo do parecer em debate. Dessa maneira, Barros expõe as semelhanças de discursos aparentemente opostos no plano das ideias, mas muito próximos em sua forma, seriam uma das responsáveis pela falta de diálogo e compreensão entre Portugal e Brasil.

Enquanto o baiano busca realizar um caldeamento dessas posições, reafirmando o propósito de União que deveria ser a direção dos debates, o mesmo deputado Moura que, quatro meses depois, em julho, justificaria a necessidade do envio de tropas para o Brasil, fez questão de defender a fala de Fernandes Tomás, criticando aqueles que chamaram seu companheiro à ordem. Assim, a proximidade com o ideário integracionista, anteriormente ressaltado, mais uma vez se torna perceptível em seus discursos.

Dias antes, quando se discutia a formação da Comissão que trataria dos negócios do Brasil, ao invés de encaminhar a discussão para o extremo do "Adeus, Sr. Brasil", Borges Carneiro demonstrara posição mais moderada. O deputado, ainda que compartilhando dos ideais liberais portugueses, faz a ressalva:

[...] querer em tudo medir o Brasil por aquilo que resolver para a Europa é incoerente, e muito errado; e querendo nós ter aquele longínquo continente na mesma dependência de Lisboa em que dela estão as províncias europeias, não faremos mais que relaxar os vínculos da união quando os queremos segurar: é apertar a corda, até que estale. ${ }^{43}$

Ele seria um dos poucos a reconhecer isso, conforme lembra Catroga ${ }^{44}$. A dimensão pluricontinental que a Nação Portuguesa buscava concretizar em sua Constituição resultava em múltiplos projetos. Borges Carneiro acreditava na necessidade de dotar de certa autonomia as províncias da América, subordinando-as possivelmente a outro centro executivo, que não a Europa - proposta controversa entre os representantes europeus, que, muitas vezes, viam-na como uma fissura na soberania nacional. Ao mesmo

\footnotetext{
${ }^{43}$ DIÁRIO, 12.03.1822, p. 446.

${ }^{44}$ CATROGA, 2014, p. 299.
} 
tempo, Carneiro sustentaria, no mesmo discurso, que não era necessária a presença de deputados vindos de todas as porções da nação portuguesa, pois:

Os povos em elegendo os seus representantes tem concluído toda a sua função. Neles se comprometem, e obrigam-se em suas procurações a aprovar o que eles com os mais da Nação fizerem na assembleia nacional. [...] os Deputados só hão de opinar como entenderem que é bem, e ao que se vencer por maioria hão de obedecer os povos constituintes conforme os seus juramentos e as suas procurações [...]. Portanto estando aqui já muitos Deputados da Europa, e Ultramar, é suficiente número para tratarem o negócio em questão sem que seja necessário esperar por todos os do Brasil, Mato Grosso, Ásia, e África ${ }^{45}$.

Portanto, embora sua postura "conciliadora" se faça presente ao assumir que é necessária uma certa autonomia para as províncias da América, ao menos no tocante ao poder executivo, quanto ao legislativo, sua postura também era radical. Uma vez eleitos, os deputados representavam a Nação como um todo, não importando a província que os elegera, assim, o geral predominaria sobre o particular. Conforme dito no início deste artigo, contrariando o centralismo de Pombal, mas também a tradição pactuária da teoria escolástica, os vintistas buscavam instaurar uma soberania que residia essencialmente na nação: "De certo modo, a nação ocupava o lugar de Deus, pelo que a autossuficiência da sua essencialidade implicava não só a unidade e indivisibilidade, mas também queria dizer que ela mantinha, constantemente, o seu poder constituinte" 46 . Esse pode ser considerado o cerne do ideário vintista, que, apesar de suas arestas no tocante à estruturação do aparato administrativo do Estado português, tinha na centralização da soberania nacional uma de suas forças.

Seguindo os apontamentos do historiador português, o que veremos aqui é início de um processo que daria forma ao Estado-nação imperial português, projeto que perduraria até a Revolução dos Cravos em 1974 ${ }^{47}$. O autor sintetiza os objetivos dos vintistas da seguinte maneira:

Em nome da racionalização da arte de governar, os movimentos revolucionários, que reivindicavam a urgência da modernização da sociedade segundo o modelo francês e o da Constituição liberal espanhola de 1812, irão atacar, no primeiro momento de afirmação do seu poder as, para eles,

\footnotetext{
${ }^{45}$ DIÁRIO, 12.03.1822, p. 446

${ }^{46}$ CATROGA, 2014, p. 294.

${ }^{47}$ CATROGA, 2014, p. 11.
} 
anacrônicas autonomias "periféricas”, em nome de critérios que combinavam o enquadramento da população com uma divisão "geométrica" do território. ${ }^{48}$

Essas pretensões estão diretamente ligadas à tentativa de pôr em prática o princípio da soberania nacional sobre um território descontínuo, com população plural em termos étnico-culturais. A inspiração dos movimentos da França e de Espanha acabava por levar os portugueses da Europa a uma maior coerência entre si, apesar das já ressaltadas divergências. Mas é a postura de "ataque" às "autonomias periféricas" que está diretamente relacionada aos grandes obstáculos enfrentados em relação às deputações vindas de províncias do Brasil.

Recém-chegada a Portugal, a deputação de São Paulo trazia consigo, além da sobredita Representação, instruções sobre sua atuação nas Cortes, que envolviam sérias críticas às medidas por elas tomadas. A proposta paulista tinha um teor claramente federativo, embora não explicitado nestes termos. Inspirados por uma tradição que vinha desde D. Rodrigo de Souza Coutinho e direcionados pelo modelo de governo proposto por José Bonifácio em consonância com os ideais do Conde de Linhares, os paulistas defendiam como grande projeto a concepção do Reino Unido. Antônio Carlos, irmão de Bonifácio, foi o principal porta-voz desses ideais. Quando se discutia a necessidade de adiar parte das votações acerca do projeto de constituição para que pudessem chegar os demais representantes das províncias do Brasil, Andrada disse:

São muito diferentes os princípios que regem um corpo homogêneo, dos que devem reger corpos compostos de partes heterogêneas; mormente quando a força repulsiva de um corpo que o impele a formar sistema diferente é tão superior a força centrípeta que o faz tender para o sistema velho, que é preciso um quase milagre de política para conservar esta união ${ }^{49}$.

As "partes heterogêneas", seriam, grosso modo, o Brasil e Portugal. O deputado paulista deixa claro que vê os dois reinos não como iguais, e sim como partes tão distintas que mantê-los sob uma união centralizada por uma "força" seria quase um milagre. Aqui,

${ }^{48}$ CATROGA, 2014, p. 16.

${ }^{49}$ DIÁRIO, 06.03.1822, p. 378. 
é atacada frontalmente a concepção "integracionista". Embora diplomado em direito pela Universidade de Coimbra, ele utiliza de metáfora próxima aos estudos de seu irmão, José Bonifácio, que inclui a filosofia natural. Em um paralelo com as leis da química, as medidas tomadas pelas Cortes até então - que pressupunham uma nação homogênea, "integral" - seriam inapropriadas para a realidade da nação portuguesa, composta por “corpos heterogêneos". O apelo à metáfora científica visava legitimar sua proposta: um sistema que articulasse ambos os reinos, dotando-lhes de autonomia. O paulista, mantendo o discurso da "ciência natural", vai além e insinua que um desses "corpos" (no caso, o Brasil) estaria fortemente impelido a diferenciar-se, uma vez que a força centrípeta (centralização das Cortes) levaria ao "sistema velho" (colonial). Por fim, fugindo da ciência, atribui ao irracional "milagre" a manutenção da união, deixando bem clara sua pouca fé nesta - sobretudo quando, como se tratava na discussão em específico, não se possibilitava a participação dessas "diferentes partes”, ainda ausentes no debate.

Márcia Regina Berbel vai além na análise das divergências concepções de nação:

\begin{abstract}
Chocavam-se, aí, as duas concepções básicas sobre a organização do Estado nacional português. De um lado, os parlamentares lusos pensavam a nação como um todo orgânico, anterior a qualquer acordo, integrado política e/ou economicamente, que se expressava no Estado por meio das Cortes e da Constituição. De outro lado, os deputados do Brasil concebiam a integração com base no acordo entre os representantes provinciais, capazes de compor a nação em um pacto social. A nação/tradição, formada pela história, chocavase com a nação/Estado, formada pela política $^{50}$.
\end{abstract}

Nessa passagem a autora mobiliza duas categorias gerais, "lusos" e "deputados do Brasil", que, embora correspondam em certa medida às concepções que lhes são associadas, não devem ser transpostas imediatamente para uma análise específica. Localizada ao fim do estudo realizado por Berbel, a passagem diz antes de um contorno final, quando o antagonismo entre deputados vindos da América e aqueles oriundos da Europa atingia seu ápice. Porém, análises que considerem os momentos particulares, mais restritos, evidenciam posturas multifacetadas. A leitura do Diário apresenta ideias que se antagonizavam, mas que podem ser encontradas nos discursos de um mesmo indivíduo

${ }^{50}$ BERBEL, 1999, p. 195. 
ou presentes tanto na fala de um europeu quanto de um brasileiro. Isso porque essas concepções, mobilizadas em um contexto discursivo específico, podem indicar uma mudança de postura, um entendimento diverso para uma temática determinada ou simplesmente uma tentativa de legitimar/convencer o público alvo. Assim veremos, em alguns momentos, brasileiros mobilizando personagens, histórias, batalhas de um passado "nacional” e, em outros, europeus apelando para o caráter contratual da nação, como algo ainda não consolidado, que somente tomaria forma no futuro.

Retomando a divergência propriamente dita, o que Berbel aponta é a presença de concepções distintas da nação, não somente no tocante à sua composição - única, centralizada, orgânica ou plural, descentralizada, artificial - mas também em relação à temporalidade que a cerca. Pensá-la como uma tradição, um passado compartilhado, implica trazer para o presente toda a sua carga, com elementos memoriais de forte apelo para aqueles que os partilham, enfatizando permanências. Já o entendimento da nação como uma elaboração do presente, fruto dos (des)acordos políticos, significa a secundarização de elementos identificadores em prol da transformação, da construção de um novo arranjo político que, dessa forma, flexibiliza as possibilidades daquela "Nação" que será feita. Embora a associação entre o local de origem do deputado com essas concepções seja questionável, havia de fato uma concorrência entre ambas.

\section{CONSIDERACÕES FINAIS}

O movimento vintista trouxe uma grande transformação da tradição política portuguesa, encaminhando a consolidação de um novo entendimento do poder soberano, transferido do rei para a Nação - o que dá agência à comunidade humana organizada politicamente. Porém, a centralização como elemento constituidor da estrutura política é mantida. Há, portanto, uma tensão, conforme já ressaltado, entre a preservação de estruturas e o desejo de transformação. Essa ambiguidade perpassou todo o movimento liberal e refletiu-se na forma como o movimento foi designado pelos seus contemporâneos, que se moviam entre "revolução" e "regeneração".

Havia, portanto, significativa fluidez na forma como os acontecimentos iniciados no Porto eram tratados e nomeados por seus contemporâneos. Em meio a essa indefinição, aquelas pessoas elaboravam seus discursos, explorando brechas que favorecessem suas 
pretensões. Em um cenário marcado pela transição e instabilidade, saber explorá-las em discursos, em plenas Cortes constituintes (centro político por excelência para a formação institucional da Nação portuguesa), tornou-se uma das principais armas nos embates travados pela hegemonia de um ou outro projeto político. Nessas disputas, ganharia vulto a concorrência justamente entre projetos que apresentavam diferentes alternativas para as relações entre um “centro" imperial - posição historicamente ocupada por Lisboa - e as periferias, dentre as quais, as possessões ultramarinas e, mais especificamente, o Brasil, que desde 1815 fora elevado à posição de Reino Unido, se destacava. Em síntese: no entrelugar da "nação" como corpo indivisível, oriundo de um passado compartilhado por um grupo humano que partilhava língua, religião e obediência a um mesmo centro de poder, encarnado na figura do rei-soberano, e a "nação" como corpo político, elaborada por pessoas que, por desejo próprio, se reuniam sob o mesmo governo e sob as mesmas leis, abriu-se o espaço de negociação e conflito entre diferentes projetos políticos que incapazes de articular centro e periferia da Nação portuguesa, impulsionaram o constituir de uma nação outra, o Brasil.

\section{REFERÊNCIAS}

\section{Fontes}

BLUTEAU, Raphael. Vocabulário português e latino. Coimbra: Real Colégio das Artes da Companhia de Jesus, 1728.

DIÁRIO das Cortes Geraes e Extraordinárias da nação portuguesa (1821-1822). Lisboa, 1821-1822. 20v.

PORTUGAL. Bases da Constituição da Monarquia Portuguesa. Lisboa: Tipografia de J. F. M. de Campos, 1821.

REPRESENTAÇÕES que à Augusta presença de Sua Alteza Real, o Príncipe Regente do Brasil, levaram o Governo, o Senado da Câmara, e Clero de São Paulo; (...). Rio de Janeiro: Imprensa Nacional, 1822.

\section{Obras Gerais}

ALEXANDRE, Valentim. Os sentidos do Império - questão nacional e questão colonial na crise do Antigo Regime português. Porto: Afrontamento, 1993. 
BERBEL, Márcia Regina. A nação como artefato: deputados do Brasil nas Cortes Portuguesas - 1821-1822. São Paulo: Hucitec: Fapesp, 1999.

CARVALHO, José Murilo de. História Intelectual no Brasil: A retórica como chave de leitura. UFRJ. Topoi. n.1, p. 123-152. Jan./Dez., 2000.

CASTRO, Zilia Osório de. Cultura e Política: Manuel de Borges Carneiro e o Vintismo. Lisboa: Instituto Nacional de Investigação Científica/Centro de História da Cultura da Universidade Nova de Lisboa, 2014. 2v.

CATROGA, Fernando. A geografia dos afectos pátrios: as reformas políticoadministrativas (séc. XIX-XX). Coimbra: Edições Almedina, 2014.

CHIARAMONTE, José Carlos. Metamorfoses do conceito de nação durante os séculos XVII e XVIII. In: JANCSÓ, István (Org.). Brasil: Formação do Estado e da Nação. São Paulo: Hucitec; Ed. Unijuí; Fapesp, 2003. (Estudos Históricos, 50)

GOMES, David Lopes. A Constituição de 1824 e o problema da modernidade: o conceito moderno de Constituição, a história constitucional brasileira e a teoria da Constituição no Brasil. Belo Horizonte: Editora D’Plácido, 2019.

PAMPLONA, Marco A. Nação. In: JÚNIOR, João Feres (Org.). Léxico da história dos conceitos políticos do Brasil. $2^{\mathrm{a}}$ ed. rev. e ampl. Belo Horizonte: Editora UFMG, 2014.

PEREIRA, Luisa Rauter. Povo/Povos. In: JÚNIOR, João Feres (Org.). Léxico da história dos conceitos políticos do Brasil. $2^{\mathrm{a}}$ ed. rev. e ampl. Belo Horizonte: Editora UFMG, 2014

. Soberania. In: JÚNIOR, João Feres (Org.). Léxico da história dos conceitos políticos do Brasil. $2^{a}$ ed. rev. e ampl. Belo Horizonte: Editora UFMG, 2014

POCOCK, J. G. A. Linguagens do ideário político. São Paulo: Edusp, 2003.

VILLALTA, Luiz C. El-Rei, os vassalos e os impostos: concepção corporativa de poder e método tópico num parecer do Códice Costa Matoso. Varia História, Belo Horizonte, V.21, p. 222-2236, 1999a.

Reformismo Ilustrado, censura e práticas de Leitura: Usos do Livro na América Portuguesa. Tese de Doutorado. Universidade de São Paulo, 1999b. 